Article

\title{
Water Quality Study on the Hot and Cold Water Supply Systems at Vietnamese Hotels
}

\author{
Kanako Toyosada ${ }^{1, *}$, Takayuki Otani ${ }^{1,2}$, Yasutoshi Shimizu ${ }^{3}$ and Shunsuke Managi ${ }^{2}$ \\ 1 Department of Environmental Science, International College of Arts and Science, \\ Fukuoka Women's University, Kasumigaoka, Higashi-ku, Fukuoka 813-8529, Japan; \\ taka.otani001@gmail.com \\ 2 Urban Institute \& Departments of Urban and Environmental Engineering, School of Engineering, \\ Kyushu University, 744 Motooka, Nishi-ku, Fukuoka 819-0395, Japan; managi.s@gmail.com \\ 3 Water and Lifestyle Research Laboratory, 31-3, Munakata, Fukuoka 811-4141, Japan; yshimizu@wlrlab.com \\ * Correspondence: kanako.toyosada@fwu.ac.jp; Tel.: +81-92-692-3116 \\ Academic Editor: Enedir Ghisi \\ Received: 14 December 2016; Accepted: 8 March 2017; Published: 3 April 2017
}

\begin{abstract}
This study was conducted as part of the Joint Crediting Mechanism (JCM) of the Japanese Ministry of Economy, Trade and Industry, and the Ministry of the Environment project's preparation in Vietnam. Samples were taken from hot and cold water supplies from guest rooms' faucets in 12 hotels in Hanoi city, Vietnam, and 13 hotels in Japan for comparison. A simple water quality measurement and determination of Legionella was carried out. The results showed that residual effective chlorine-which guarantees bactericidal properties-was not detected in tap water supplied in hotel rooms in Vietnam, and nitrite (an indicator of water pollution) was detected in $40 \%$ of buildings. In the hotels in Japan, the prescribed residual chlorine concentration met the prescribed levels, and nitrite was not detected. Additionally, while there was no Legionella detected in the Japanese cases, it was detected in most of the Vietnamese hotels, which were found to manage the hot water storage tank at low temperatures of $40-50{ }^{\circ} \mathrm{C}$. It was found that there were deficiencies in cold and hot water supply quality, and that there was no effective system in place for building operation maintenance and management.
\end{abstract}

Keywords: water saving; water quality; Legionella; Vietnamese hotel

\section{Introduction}

The Sustainable Development Goals were adopted in 2016, following from the UN Millennium Development Goals, which had provided direction for sustainable global development. Water was recognized as an important issue for sustainable development, and global aims such as safe drinking water and use of sanitary facilities continued to be highlighted. Research was also initiated that investigated future scenarios for the relationship between water and energy [1].

Using examples from Japan and Vietnam [2,3], the authors show that one of the solutions for attaining sustainable development is the formation of water-saving societies. In Japan, it was shown that promoting such a water-saving society can contribute a reduction of $1 \%$ to the domestic $\mathrm{CO}_{2}$ emissions (reference to 1990) by 2020. As a result, there is an accepted method of calculating $\mathrm{CO}_{2}$ reduced by the spread of water-saving household equipment (e.g., water-saving toilets), in order to obtain domestic credits [4]. Water-saving projects for credit have already begun [4].

The $\mathrm{CO}_{2}$ emissions reduction achieved by saving water is also adopted in the bilateral crediting scheme, the Joint Crediting Mechanism (hereafter referred to as JCM) managed by the Japanese Ministry of Economy, Trade and Industry, and the Ministry of the Environment. Vietnam is currently also preparing to launch a JCM project. 
Vietnam experiences interruptions of water and electricity services, as the current system cannot cope with the increased water and power demands from rapid urbanization. In a study on JCM project feasibility, it was revealed that the water consumption reduction achieved by the proliferation of water-saving equipment could contribute to both a reduction of energy usage by the water and sewage systems, and the more efficient use of water resources. A $2500-4500 \mathrm{~W}$ electric water heater is used by Vietnamese households and small-scale hotels for showers. Their usage in the evening forms a peak in power use, and the spread of water-saving showers can contribute to lowering peak consumption [3]. As a result, both Japanese and Vietnamese government officials recognize that working towards a water-saving society is an effective and useful contribution to Vietnam's green growth goals. Thus, the JCM project is currently in the stage of developing the business environment for the spread of water-saving products. In this development stage, business models are being created for different market segments, such as hotels, office buildings, and housing, for the adoption of water-saving products.

This study reports on the issues and relevant strategies that have emerged in the process of preparing technical frameworks for possible JCM project sites (such as new hotel and office buildings), and contributes to the ongoing preparations for JCM projects in Vietnam.

When spreading water-saving products in Vietnam, it is important to ensure that the safety (i.e., the water quality) of hot and cold water supplies is maintained. Yet, the tap water is not even drinkable in five-star hotels in Vietnam. According to Vietnam's Water Supply and Sewerage Association, in Vietnam it is necessary to keep the water pressure of the water mains low because of the high leakage rate of water supply piping. The result of this is that water from the leaking pipes mixes with ground water, and it is said that this is what causes pollution of the water supply.

To date, studies on water supply have found insufficient residual chlorine concentration in some water supplies [5]. Some studies have detected the presence of Legionella bacteria in hot water supply systems [6-9]. One study also found that there was Legionella bacteria in a filled tub in a Japanese bathing facility. However, there have been no studies on the occurrence of Legionella in operating Vietnamese hotels and the processes involved in hot water supply. Therefore, as part of the JCM project's business environment development, this study investigated the water quality of operating Vietnamese hotels. This included measuring the residual chlorine concentration of water from each room's faucet; the temperature of hot water from bathroom faucets; and basic measurement of Legionella bacteria. The study explores issues and measures related to a water-saving JCM project.

\section{Method}

\subsection{Analyzing the Quality of Hotels' Hot and Cold Water Supply}

The focus of the investigation was on 12 buildings, which were 3-5 star hotels and serviced apartments (henceforth "hotels") in Hanoi City, Vietnam. A water quality analysis was carried out using the residual active chlorine concentration as an indication of the bactericidal effect and the nitrite-nitrogen concentration as an indicator of pollution. For comparison, the same water quality analysis was also carried out at 13 Japanese hotels. Japanese business hotels that were located in urban areas such as Tokyo were targeted, and as "years in operation" was considered to have an impact on water quality, we chose a wide range from those that had been in operation for many years to only a few years. An outline of the hotels investigated, including number of rooms, construction year, and years of operation, is shown later in the paper with study results in Table 1. Analysts stayed at each of the hotels and took water samples from each room's taps in order to conduct a simple measurement of water quality. 
Table 1. Analysis results showing hot and cold water supplies' water quality in hotel rooms in Vietnam and Japan.

\begin{tabular}{|c|c|c|c|c|c|c|c|c|c|c|c|c|}
\hline NO. & & $\begin{array}{c}\text { Years of } \\
\text { Operation }\end{array}$ & $\begin{array}{l}\text { Approximate } \\
\text { NO. of Rooms }\end{array}$ & $\begin{array}{l}\text { Inspection } \\
\text { Date }\end{array}$ & $\begin{array}{l}\text { Hot Water } \\
\text { Supply Type }\end{array}$ & $\begin{array}{l}\text { Hot Water Supply } \\
\text { Temperature }\left({ }^{\circ} \mathrm{C}\right)\end{array}$ & $\begin{array}{l}\text { Residual Effective } \\
\text { Chlorine } \\
\text { Concentration (mg/L) }\end{array}$ & $\begin{array}{c}\mathrm{TH} \\
(\mathrm{mg} / \mathrm{L})\end{array}$ & $\begin{array}{c}\mathrm{Fe} \\
(\mathrm{mg} / \mathrm{L})\end{array}$ & $\begin{array}{c}\mathrm{NO}_{2} \\
\text { Concentration } \\
(\mathrm{mg} / \mathrm{L})\end{array}$ & $\mathrm{pH}$ & $\begin{array}{c}\text { Legionella } \\
\text { Detection in Ho } \\
\text { Water Supply }\end{array}$ \\
\hline (1) & Hanoi & 11 & 300 & $5 / 10 / 2014$ & Centralised & 47 & ND & 100 & 0.5 & 0.02 & 8 & + \\
\hline (2) & Hanoi & 22 & 200 & $3 / 11 / 2014$ & Centralised & 41.5 & ND & 100 & 0.3 & 0.02 & 7.5 & + \\
\hline (3) & Hanoi & 20 & 80 & $4 / 11 / 2014$ & Centralised & 40 & ND & 200 & 0.5 & 0.05 & 8.5 & + \\
\hline (4) & Hanoi & 1 & 300 & $18 / 11 / 2014$ & Centralised & 59.2 & ND & 100 & ND & ND & 7.5 & - \\
\hline (5) & Hanoi & 2 & 100 & $19 / 11 / 2014$ & Centralised & 43.5 & 0.1 & 100 & ND & ND & 8.5 & + \\
\hline (6) & Hanoi & 6 & 40 & $19 / 11 / 2014$ & Centralised & 29.8 & ND & 100 & 0.3 & 0.02 & 7.5 & + \\
\hline$(7)$ & Hanoi & 18 & 200 & $22 / 11 / 2014$ & Local electric & 65.1 & 0.1 & 100 & 0.3 & ND & 7 & - \\
\hline (8) & Hanoi & 16 & 400 & $29 / 11 / 2014$ & Central & 46 & ND & 100 & ND & ND & 8.5 & + \\
\hline (9) & Hanoi & 18 & 250 & $13 / 01 / 2015$ & Centralised & 58.7 & 0.1 & 50 & ND & ND & 7 & - \\
\hline (10) & Hanoi & 3 & 200 & $14 / 01 / 2015$ & Centralised & 51.2 & ND & 50 & ND & ND & 7 & - \\
\hline (11) & Hanoi & 6 & 300 & $25 / 01 / 2015$ & Centralised & 41.8 & 0.1 & 100 & ND & ND & 7 & + \\
\hline (12) & Hanoi & 16 & 250 & $26 / 01 / 2015$ & Centralised & 62.5 & ND & 100 & ND & ND & 8.2 & - \\
\hline (1) & Tokyo & 8 & 350 & $27 / 10 / 2014$ & Centralised & 58.5 & 0.6 & 50 & 0.3 & ND & 7.5 & \\
\hline (2) & Tokyo & 1 & 300 & $2 / 11 / 2014$ & Centralised & 60.4 & 0.6 & 50 & ND & ND & 7.5 & - \\
\hline (3) & Tokyo & 12 & 300 & $7 / 11 / 2014$ & Centralised & 59.2 & 0.6 & 50 & 0.3 & ND & 8 & - \\
\hline (4) & Tokyo & 21 & 3700 & $7 / 11 / 2014$ & Centralised & 55.3 & 0.4 & 50 & ND & ND & 7.5 & - \\
\hline (5) & Tokyo & 7 & 150 & $3 / 12 / 2014$ & Centralised & 63.8 & 0.6 & 100 & ND & ND & 7.5 & - \\
\hline (6) & Tokyo & 9 & 200 & $4 / 12 / 2014$ & Centralised & 59.9 & 0.6 & 50 & ND & ND & 7.5 & - \\
\hline (7) & Tokyo & 21 & 100 & $15 / 12 / 2014$ & Centralised & 58.5 & 0.4 & 50 & ND & ND & 7.5 & - \\
\hline (8) & Kanazawa & 21 & 10 & $18 / 12 / 2014$ & Centralised & 66 & 0.6 & 20 & $\mathrm{ND}$ & ND & 7.5 & - \\
\hline (9) & Kanazawa & 25 & 250 & $19 / 12 / 2014$ & Centralised & 66.6 & 0.6 & 50 & $\mathrm{ND}$ & ND & 7 & - \\
\hline (II) & Fukuoka & 43 & 250 & $26 / 12 / 2014$ & Centralised & 60.3 & 0.8 & 20 & ND & ND & 7.5 & - \\
\hline (11) & Nagasaki & 27 & 150 & $5 / 12 / 2014$ & Centralised & 55.1 & 0.4 & 10 & ND & ND & 7 & - \\
\hline (12) & Tokyo & 11 & 400 & $12 / 01 / 2015$ & Centralised & 60.8 & 0.4 & 50 & ND & ND & 8 & - \\
\hline (13) & Chiba & 6 & 200 & $21 / 01 / 2015$ & Centralised & 64.5 & 0.6 & 20 & ND & ND & 7 & - \\
\hline
\end{tabular}

Notes: ND: Not Detected; +: Detected; -: Not Detected. 
Vietnam's tap water quality is regulated by the "Decision on standards of drinking water applying to food and beverage: Decision 1329/2002/BYT/QD". Similar to developed countries, a safe water supply is free from metal ions, organic matter contamination, and microbial contamination, which are health concerns. Typical tap water quality items and reference values are shown in Table 2. To compare, these are shown alongside the Japanese water quality standards. With regard to nitrite nitrogen, the drinking water quality guidelines of the WHO (World Health Organization) determined that the influence on the human body is uncertain, and so include a provisional value. However, in Japan, the value was officially determined in 2014, and even in Vietnam the standard values are defined (as shown in Table 2). Therefore, it was analyzed in this study. In tap water quality analysis, a Shibata Science simple water quality test kit was used. The analysis principles and measurement range is shown in Table 3.

Table 2. Comparison of Vietnam and Japan's water supply water quality standard values.

\begin{tabular}{cccc}
\hline Item & Unit & $\begin{array}{c}\text { Vietnam's Standard * } \\
\text { (Maximum Value) }\end{array}$ & $\begin{array}{c}\text { Japan's Standard ** } \\
\text { (Maximum Value) }\end{array}$ \\
\hline Residual chlorine & $\mathrm{mg} / \mathrm{L}$ & 0.5 & 1 \\
Chromaticity & $\mathrm{TCU}$ & 15 & 5 \\
Turbidity & $\mathrm{NTU}$ & 2 & 2 \\
Odor & - & No abnormality & No abnormality \\
pH & - & $6.5-8.5$ & $5.8-8.6$ \\
Nitrate nitrogen & $\mathrm{mg} / \mathrm{L}$ & 50 & 10 \\
Nitrite nitrogen & $\mathrm{mg} / \mathrm{L}$ & 3 & 0.04 \\
Iron & $\mathrm{mg} / \mathrm{L}$ & 0.5 & 0.3 \\
Coliform group & - & 0 & 0 \\
\hline
\end{tabular}

Notes: * Water quality standard values were determined by Vietnam's Decision 1329/2002/BYT/QD; ** Tap water quality standard value stipulated by "Ministerial Order on Water Quality Standards" based on Article 4 of the Waterworks Act of Japan.

Table 3. Tap water quality analysis $[10,11]$.

\begin{tabular}{ccc}
\hline Item & Measurement Principle & Range (mg/L) \\
\hline Free residual chlorine & Diethyl-p-phenylenediamine ammonium method & $0.1-5.0$ \\
Nitrite nitrogen & Sulfanilamide-naphthylethylenediamine method & $0.02-1.00$ \\
Iron & o-Phenanthroline method & $0.3-10.0$ \\
Total hardness & Phthalein Complexone method & $0-200$ \\
$\mathrm{pH}$ & Bromothymol blue method & $5.8-8.0$ \\
\hline
\end{tabular}

Moreover, in JCM project feasibility studies to date, it has been confirmed that a number of Vietnamese hotels supply hot water at lower than optimum temperatures, and therefore the possibility of contamination of the water by microorganisms was also analyzed. Regarding the microorganism risk of the hot water supply, this risk includes Legionella bacteria, which can cause Legionella pneumonia if breathed in from hot water vapor from showering, etc.

Legionella is a bacterium that can be found in natural soil and fresh water sources. As it lives and grows inside protozoans such as amoebas that occupy $20-50{ }^{\circ} \mathrm{C}$ habitats, it can be found growing in biofilms where protozoans are present. Possible environments where the water may stay within this temperature range for long periods of time include buildings' cooling towers, ornamental ponds, circulation-type bathtubs, and hot water supply systems. People who inhale water vapor that contains Legionella bacteria may develop Legionnaires' disease. Those with weakened or compromised cellular immunity are at a greater risk, and thus infection occurs more often in elderly people. The term Legionnaires' disease was discovered following a pneumonia outbreak that occurred in service members of the American Legion in Philadelphia, United States, in 1976.

Cases caused by the Legionella bacteria have been reported in countries around the world, including Japan and the United States. Therefore, a simple analysis was carried out on each bathroom 
faucet's hot water to determine the presence of Legionella bacteria in Vietnamese hotels' hot water supply, using Legio Search technology of Yuki Chemical Co., Ltd., Niigata, Japan. The method is a simple analysis method based on antigen-antibody reaction to the Legionella pneumophila group 1, with samples under $50 \mathrm{CFP} / 100 \mathrm{~mL}$ being defined as negative. Legio Search was used because it was necessary to transport analytical instruments from Japan and bring them to the rooms of each hotel in Vietnam. It is lightweight and easy to handle. Measuring with the maximum hot water temperature, X-ray photoelectron spectroscopic analysis of the hot water supply $20 \mathrm{~L}$ ( $\$ 47 \mathrm{~mm}$ glass fibre microfiltration membrane) was also performed. The reason why X-ray photoelectron spectroscopy (XPS) was carried out was to observe the particulate matter contained in tap water.

\subsection{Interviews and On-Site Investigations}

In October 2014-January 2015, water quality analysis of the hot and cold water supply systems for four hotel facilities (1)(2) (3)(10) in Table 1) was carried out. The researchers observed the rear area of the hotel and confirmed the installation conditions of water supply tanks, hot water supply boilers, hot water storage tanks, water supply/hot water supply pipes in rooms and circulation pumps, which were installed in machine rooms and on rooftops. Regarding the operation, maintenance, and management situation, we conducted an interview survey with the hotel's managing technician. In the interview, questions were asked such as: "What is the water supply system of the hotel? / Do you measure the water supply quality of the building?/At what temperature is the hot water storage tank managed?/Is there cross connection in the water/hot water supply pipes?" The sample of hotels selected included those that were built and operated using Vietnamese capital, and those that were built and operated using American and Singaporean capital.

Additionally, interviews were carried out with Japanese building companies that were undertaking large-scale building design in Vietnam. This provided an overview of the design and construction of large-scale buildings such as hotels.

\section{Results and Discussion}

\subsection{Analysis of Hotels' Water Supply Quality}

In Vietnam, to maintain the water quality values shown in Table 2, the water supply system functions in the same way as developed countries, with water supplied after treatment with rapid filtration and chlorine disinfection. Following that, the tap water passes through the building's internal water supply system and is distributed to users. All water supply systems of the hotels investigated in this study used an elevated water tank system. According to the interviews with design businesses, the majority utilize the elevated water tank system.

The results of water quality analysis of the water supplied to each hotel room in Vietnam and Japan are shown in Table 1 and Figure 1. In the water supplied to Vietnamese hotel rooms, residual active chlorine that maintains bactericidal properties was not detected. Further, nitrite was present in $40 \%$ of buildings - an indicator of water pollution. Additionally, the film from $20 \mathrm{~L}$ of filtered tap water is shown in Figure 1. It was revealed that in almost all of the facilities-including five-star hotels that had been constructed in the past year-particulate matter supplemented by the microfiltration membrane was mixed with the water supply, and chlorine that had been added at the water treatment facility was being consumed. Therefore, it is possible that the contamination of the tap water occurred prior to being supplied to the building's water supply system.

As outlined above, according to Vietnam's Water Supply and Sewerage Association, in Vietnam, the deterioration of water supply piping has caused widespread leakage (the leakage rate is $30 \%$ ). As there are many leaks, it is impossible to raise the pressure of the water pipes. Since the water pipes are buried underground, if the pressure of the water pipe is low, groundwater, etc. is likely to become mixed with tap water through cracked parts of the pipes. Therefore, there is a high probability that the source of pollution is ground water that has mixed in with tap water in underground pipes. 
Additionally, it was confirmed in interviews with building managers that maintenance to protect hotel water quality was not carried out. Moreover, it was determined that water contaminated from leaking parts of underground buried piping was supplied to guest rooms in that state. In an interview with a hotel's manager (technician), it was revealed that there was no cross-connection between the hot/cold water supply piping and other lines in the hotel building. However, we cannot completely exclude the possibility that the cause of contamination is a cross-connection, because it was not possible to investigate the existence of cross-connection in this survey.

To compare, the same analysis was carried out in Japanese hotels. The results are displayed in Table 1 and Figure 1. According to legislation on water systems in Japan, the residual active chlorine concentration of water supplied from the faucet is required to be above $0.1 \mathrm{mg} / \mathrm{L}$. Accordingly, in all of the hotels in the study, levels over $0.4 \mathrm{mg} / \mathrm{L}$ were detected. Additionally, there was no contamination of the particulate components supplementing the membrane filters. To date, the researchers have investigated the water supply system of Vietnam and found that its water quality has been maintained at the same level as Japan [12]. Therefore, as stated above, contamination of the tap water is likely to be caused by groundwater entering the underground water supply pipe. Additionally, even if contaminated water is supplied to the building, no counter-measures have been taken by the building's management, such as the addition of residual chlorine. As such, it may be concluded that the absence of building maintenance operations in Vietnam is an issue. In Japan, there are established systems that give maintenance personnel a management education, and the Act on Maintenance of Sanitation in Buildings obliges maintenance managers of buildings' water supply systems to acquire national qualifications on maintenance and obliges them to attend classes on a regular basis. Conversely, interviews with relevant managers in Vietnam revealed that similar regulations and education systems for managers were undeveloped.

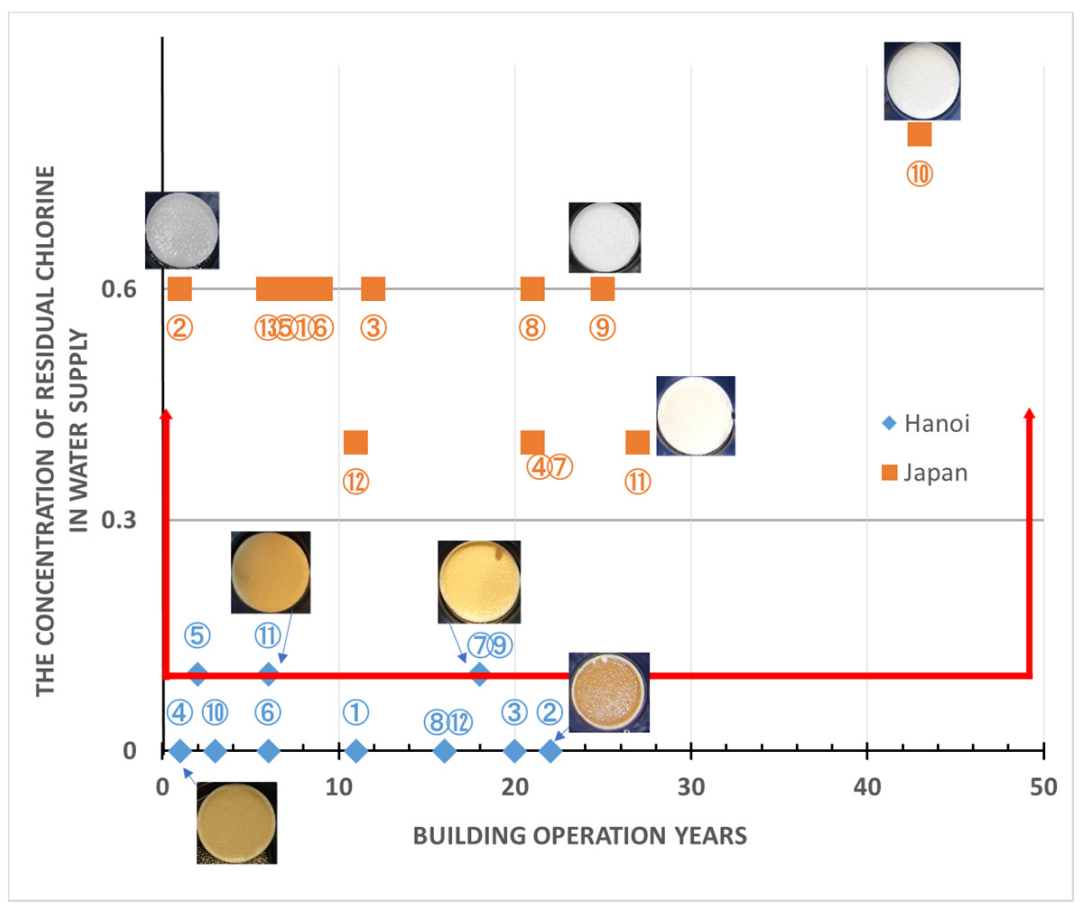

Figure 1. Residual effective chlorine concentration in tap water supplied in hotel rooms.

\subsection{Legionella Study of Hotels' Hot Water Supply}

In Japan, measures against Legionella are taken at both the design and construction stage and the maintenance stage, and the aim is to reduce the risk of disease from Legionella for the whole of society. In 1994, the building management education center issued Legionnaires' disease prevention guidelines 
as measures for the building maintenance stage. In 2006, the Society of Heating, Air-Conditioning and Sanitary Engineers of Japan enacted regulations to prevent Legionella at the design and construction phase of buildings aimed at bathing facilities. Legionella bacteria cannot grow in temperatures above $55^{\circ} \mathrm{C}$. Therefore, buildings' hot water supply systems in Japan are designed and maintained so that the hot water is circulated constantly and maintained at a temperature of over $55^{\circ} \mathrm{C}$. However, corrosion of piping and energy loss can occur, so temperature is controlled by the circulation flow rate to maintain a hot water storage temperature of $60{ }^{\circ} \mathrm{C}$ and recirculation temperature of $55^{\circ} \mathrm{C}$. Accordingly, all measurements of hot water supply temperatures in Japanese hotels were above $55^{\circ} \mathrm{C}$, and no Legionella was detected.

The results of the analysis are shown in Table 1 and Figure 2. Figure 3 shows an electron micrograph of the film surface supplemented with $20 \mathrm{~L}$ hot water with glass fiber microfiltration membrane of $\phi 47 \mathrm{~mm}$. However, no significant particulate contamination of the hot water was observed.

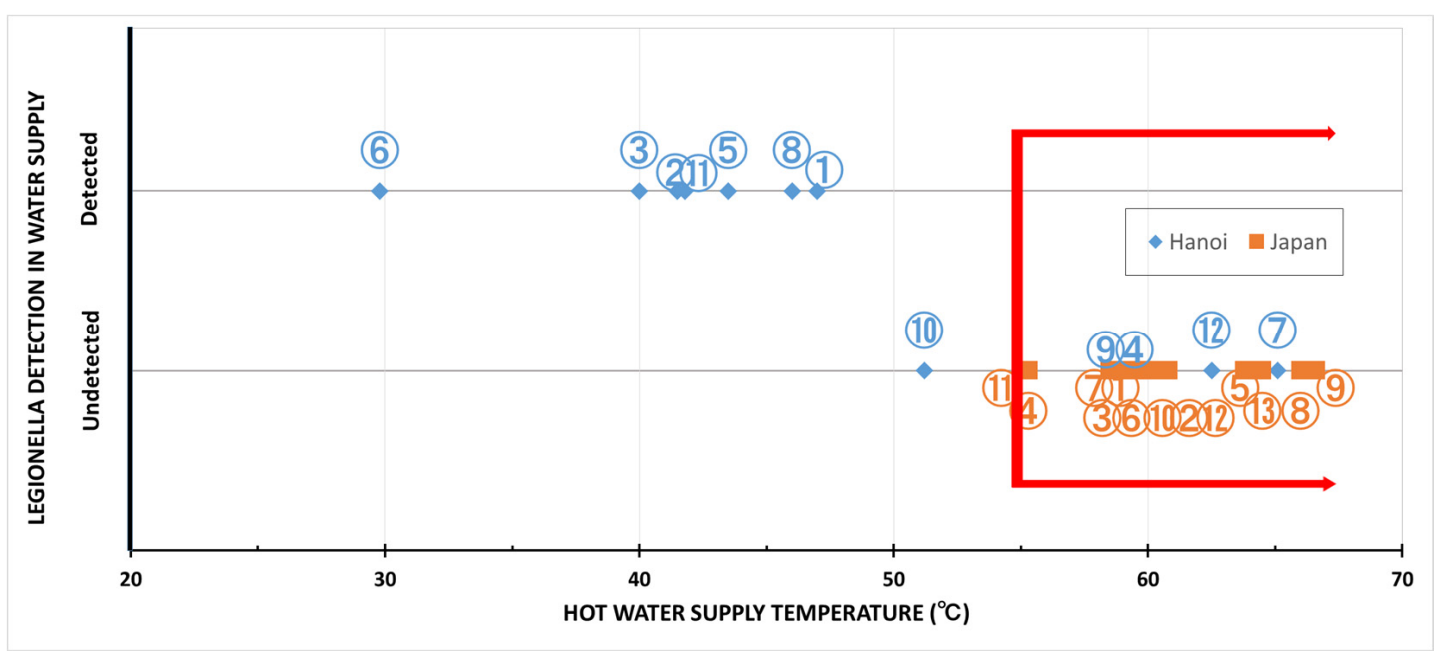

Figure 2. The supplied hot water temperature at hotels and the result of Legionella bacteria detection.

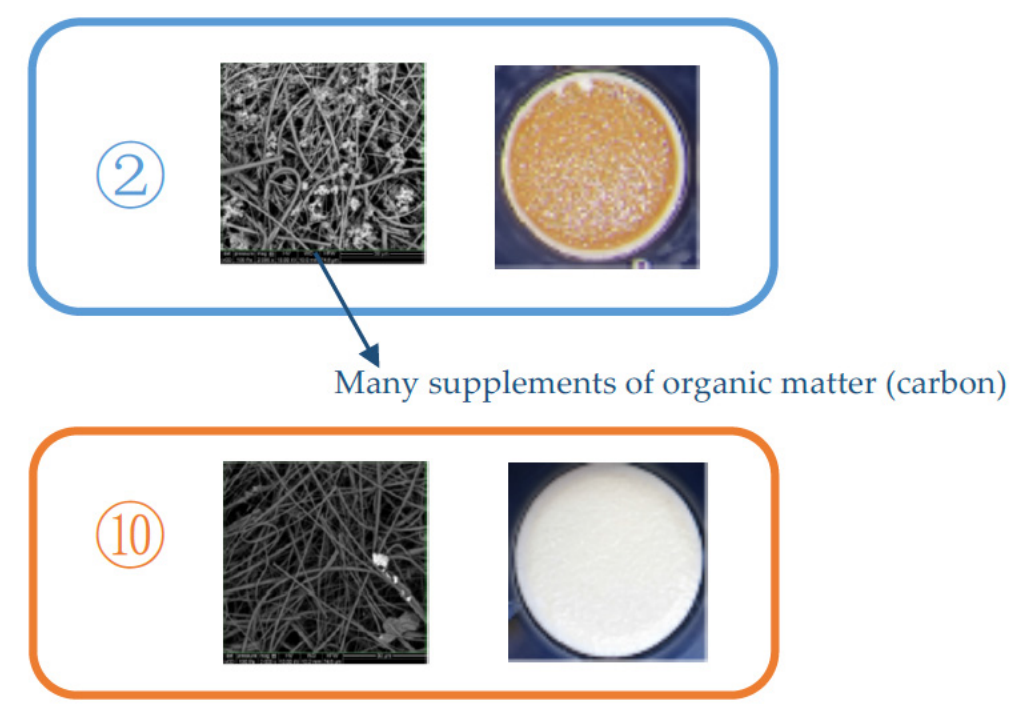

Figure 3. Filtration membranes and electron micrographs of hot water from the guest room faucets on site (2) and (10.

Conversely, in the analysis of hotels' hot water supply systems in Vietnam, the majority were $55{ }^{\circ} \mathrm{C}$ or less, creating the conditions for Legionella bacteria proliferation, and Legionella was detected. 
The measurement of Legionella levels could not be confirmed because a simple measurement kit was used; however, as shown in Figure 2, it is considered that there is a clear correlation between hot water supply temperature and presence or absence of Legionella. Even in the hot water supply membrane filtration supplement, many micro particles were observed. These were identified as organic matter (carbon) in the XPS analysis. In the Vietnamese hotels examined, the bactericidal properties of the tap water were being lost, leading to a high risk of microbial contamination of the hot water supply that could transform the tap water into raw water. Further, since the maintained temperature of the hot water supply is low, this indicates that biofilms which cause Legionella growth have formed in the hot water supply. In addition, there are small-scale hotels and serviced apartments in Vietnam which have a small electric hot water tank in each room. An example of a small storage-type electric water heater is shown in Figure 4. The compact storage-type electric water heater's hot water storage temperature is set to above $60{ }^{\circ} \mathrm{C}$, and as such, Legionella was not even detected with raw water contamination (7) in Figure 3).

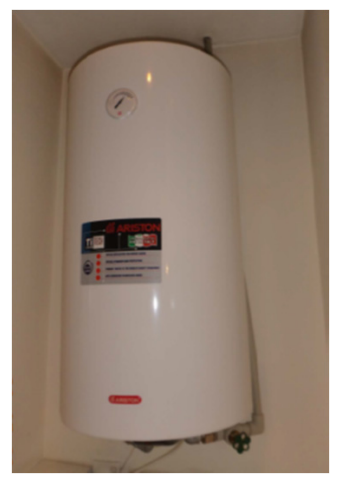

Figure 4. Example of an electrical water heater used for the shower.

\subsection{Results from Water Supply Facility Investigations}

To further explore reasons behind the prevalence of low temperature hot water supply in Vietnam's hotels, site inspections and interviews with facility management officers were carried out in addition to water quality analysis. The four facilities had hot water circulation systems yet, regarding the systems' management, the operation method was left to the individual discretion of the operations manager. For example, a timer stop valve was added to the return piping and intermittent circulation may be performed every hour. The operation methods in Table 4 show an example of the hot water supply temperature in Figure 2. It was found that the purpose of complete circulation of hot water at a lower temperature was to save on operating costs and that there was no awareness of measures against Legionella.

Table 4. Overview of hot water facilities investigated in Vietnamese hotels.

\begin{tabular}{|c|c|c|c|c|c|}
\hline No * & Heat Source & Hot Water Circulation & $\begin{array}{l}\text { Hot Water Tank Storage } \\
\text { Capacity (1 Unit) }\end{array}$ & $\begin{array}{c}\text { Hot Water } \\
\text { Tank Number }\end{array}$ & $\begin{array}{l}\text { Hot Water Tank } \\
\text { Temperature }\end{array}$ \\
\hline (1) & Heat pump & Constant & $6000 \mathrm{~L}$ & two units & $40-50^{\circ} \mathrm{C}$ \\
\hline (3) & Electric heater type & $\begin{array}{c}\text { Timer-controlled } \\
\text { Intermittent circulation }\end{array}$ & $\begin{aligned} \text { Outer circumference } & =6.6 \mathrm{~m}, \\
\text { height }=2 \mathrm{~m}, \text { volume } & =6.9 \mathrm{~m}^{3}\end{aligned}$ & three units & $42{ }^{\circ} \mathrm{C}$ \\
\hline
\end{tabular}

Note: ${ }^{*}$ The numbers correspond with Table 1.

Regarding the construction of urban infrastructure around the world, the designs of large-scale buildings are often decided by a competitive global market. As such, building designs are becoming 
standardized globally. Even in Vietnam, major Japanese architectural design and building companies are expanding, and advanced designs and building techniques have been adopted. However, maintenance and management of the buildings is left in local hands on-site.

The JCM project conducted by the Japanese government is a project aiming to contribute to the sustainable development of developing countries by providing them with the most advanced environmental Japanese technologies available. For this to be successful, it is necessary that the partner country accepts and utilizes the technology for an extended period of time. The authors posit that to support the establishment of a water-saving society, building quality must be ensured (specifically safety and security), so that buildings with water-saving products will be in long-term operation and use.

Japan has already instituted an education system for specialists in the procedures and standards of every aspect of maintenance from the building stage onward. It is important to teach the skills necessary for building maintenance, as well as providing the necessary environmental technologies, in order to contribute to sustainable development within the JCM project for water conservation.

\section{Conclusions}

This study was conducted as part of the JCM project's preparation in Vietnam. Samples were taken from the hot and cold water supplies from guest rooms' faucets in 12 hotels in Hanoi city, Vietnam, and 13 hotels in Japan for comparison. A simple water quality measurement and determination of Legionella was carried out. As a result, residual effective chlorine-which guarantees bactericidal properties-was not detected in tap water supplied in hotel rooms in Vietnam, and nitrite as an indicator of water pollution was detected in $40 \%$ of buildings. In the hotels in Japan, the prescribed residual chlorine concentration met the prescribed levels, and nitrite was not detected. Therefore, contamination of the tap water is likely to be caused by groundwater entering the underground water supply pipe. Additionally, even if contaminated water is supplied to the building, no counter-measures were taken by the building's management, such as the addition of residual chlorine. Further, while there was no Legionella detected in the Japanese cases, it was detected in most of the Vietnamese hotels, which were found to manage the hot water storage tank at low temperatures of $40-50^{\circ} \mathrm{C}$. It seems that the cause of this is the absence of an established education system for maintenance managers in Vietnam, and as such, building maintenance was not properly carried out. Regarding Legionella detection, since a simple measurement kit was used, more detailed analysis of the target sites is necessary in the future.

In order to utilize the JCM scheme promoted by the Japanese government and contribute to Vietnam's green growth, water-saving products must be spread in conjunction with securing the basic quality and safety of buildings. For this, it is necessary to develop a system for the operational management of buildings.

Acknowledgments: This study was conducted as a part of the "JCM Large Scale Feasibility Project to Promote Water Saving and Energy Saving Products in Vietnam" project, which is part of the "Project to Support the Large-Scale Formation of Joint Crediting Mechanism Programs to Realize Low Carbon Societies in Asia (FY2013)" of the Ministry of Environment of Japan. This paper is written under the "Program to support research activities of female researchers" of the Japanese Ministry of Education, Culture, Sports, Science and Technology. All the people related to these projects are hereby gratefully acknowledged for their help and support.

Author Contributions: Yasutoshi Shimizu designed the experiments; Kanako Toyosada performed the experiments; Kanako Toyosada, Takayuki Otani analyzed the data; Shunsuke Managi checked the analyzed data; Kanako Toyosada and Takayuki Otani wrote the paper.

Conflicts of Interest: The authors declare no conflict of interest.

\section{References}

1. UN-Water Decade Programme. Partnerships for improving Water \& Energy efficiency and sustainability. In Proceedings of the 2014 UN-Water Annual International Zaragoza Conference, Zaragoza, Spain, 13-16 January 2014. 
2. Otani, T.; Toyosada, K.; Shimizu, Y. $\mathrm{CO}_{2}$ Reduction Potential of Water Saving in Vietnam. Water 2015, 7, 2517-2526. [CrossRef]

3. Otani, T.; Toyosada, K.; Shimizu, Y. Contribution of Water Saving to a Stable Power Supply in Vietnam. Water 2015, 7, 2900-2907. [CrossRef]

4. Shimizu, Y.; Toyosada, K.; Yoshitaka, M.; Sakaue, K. Creation of Carbon Credits by Water Saving. Water 2012, 4, 533-544. [CrossRef]

5. Shrestha, A.; Sharma, S.; Gerold, J.; Erismann, S.; Sagar, S.; Koju, R.; Schindler, C.; Odermatt, P.; Utzinger, J.; Cissé, G. Water Quality, Sanitation, and Hygiene Conditions in Schools and Households in Dolakha and Ramechhap Districts, Nepal: Results from A Cross-Sectional Survey. Int. J. Environ. Res. Public Health 2017, 14, 89. [CrossRef] [PubMed]

6. Edagawa, A.; Kimura, A.; Kawabuchi-Kurata, T.; Adachi, S.; Furuhata, K.; Miyamoto, H. Investigation of Legionella Contamination in Bath Water Samples by Culture, Amoebic Co-Culture, and Real-Time Quantitative PCR Methods. J. Environ. Res. Public Health 2015, 12. [CrossRef] [PubMed]

7. Ditommaso, S.; Giacomuzzi, M.; Ricciardi, E.; Zotti, C.M. Efficacy of a Low Dose of Hydrogen Peroxide (Peroxy Ag+) for Continuous Treatment of Dental Unit Water Lines: Challenge Test with Legionella pneumophila Serogroup 1 in a Simulated Dental Unit Waterline. J. Environ. Res. Public Health 2016, 13. [CrossRef] [PubMed]

8. Whiley, H. Response to Comments on Whiley Legionella Risk Management and Control in Potable Water Systems: Argument for the Abolishment of Routine Testing. Int. J. Environ. Res. Public Health 2017, 14, 12. Int. J. Environ. Res. Public Health 2017, 14, 103. [CrossRef] [PubMed]

9. Jjemba, P.K.; Johnson, W.; Bukhari, Z.; LeChevallier, M.W. Occurrence and Control of Legionella in Recycled Water Systems. Pathogens 2015, 4, 470-502. [CrossRef] [PubMed]

10. Kazuno, C.; Hosouchi, A.; Shinkai, M. Quality analysis of water with simple test kit. J. Ind. Water 1996, 458, $50-61$.

11. Kazuno, C.; Hosouchi, A.; Shinkai, M. Quality analysis of water with simple test kit(2). J. Ind. Water 1998, 481, 37-49.

12. Yasutoshi, S.; Satoshi, D.; Kanako, T. The $\mathrm{CO}_{2}$ emission factor of water in Japan. Water 2012, 4, 759-769.

(C) 2017 by the authors. Licensee MDPI, Basel, Switzerland. This article is an open access article distributed under the terms and conditions of the Creative Commons Attribution (CC BY) license (http:/ / creativecommons.org/licenses/by/4.0/). 